\title{
Modul Pembelajaran Pemanfaatan Kulit Durian Untuk Meningkatkan Kemampuan Kognitif Siswa Sekolah Menegah Pertama (SMP)
}



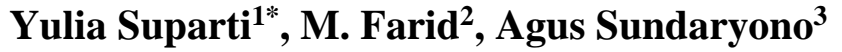 \\ ${ }^{1}$ Guru SMPN 11 Kota Bengkulu \\ ${ }^{2}$ Jurusan Fisika FMIPA, Universita Bengkulu \\ ${ }^{3}$ S2 Pendidikan IPA FKIP, Universita Bengkulu \\ *Email: yuliasuparti22@gmail.com
}

DOI: https://doi.org/10.33369/pendipa.4.3.14-19

\begin{abstract}
ABSTRAK
Penelitian ini bertujuan untuk: 1) mengetahui besarnya arus listrik pada limbah ekstrak kulit durian, 2) mengetahui besarnya Beda Potensial listrik pada limbah ekstrak kulit durian, 3) mengetahui besarnya listrik dinamis yang dihasilkan oleh limbah ekstrak kulit durian, mengetahui tingkat kualitas modul yang dirancang, 4) mengetahui peningkatan kemampuan kognitif siswa dengan menggunakan modul pada pokok bahasan Listrik Dinamis di kelas IX SMPN 11 Kota Bengkulu, dan 5) mengetahui perbedaan hasil belajar kognitif siswa pada kelompok tinggi, sedang dan rendah. Penelitian ini adalah Penelitian ini adalah merancang modul pembelajaran menggunakan limbah kulit durian sebagai sumber energi listrik pada pembelajaran listrik dinamis untuk meningkatkan kemampuan kognitif siswa kelas IX.C SMPN 11 Kota Bengkulu. Metode yang digunakan Discovery learning dengan menerapkan pembelajaran HOTS. Hasil penelitian menunjukkan: 1) Nilai rata-rata kuat arus listrik yang dihasilkan dari ekstrak kulit durian menggunakan anoda Tembaga $(\mathrm{Cu})$, Aluminium (Al), dan Besi (Fe) secara berurutan sebesar 1.175,2778 $\mu \mathrm{A}, 5,8911 \mu \mathrm{A}$, dan 0,0030 $\mu \mathrm{A}, 2)$ Nilai rata-rata tegangan listrik yang dihasilkan dari ekstrak kulit durian menggunakan anoda Tembaga $(\mathrm{Cu})$, Aluminium (Al), dan Besi (Fe) secara berurutan sebesar 2,2917 Volt, 1,2772 Volt, dan 0,4556 Volt, 3) Nilai rata-rata daya listrik yang dihasilkan dari ekstrak kulit durian menggunakan anoda Tembaga $(\mathrm{Cu})$, Aluminium $(\mathrm{Al})$, dan Besi $(\mathrm{Fe})$ secara berurutan sebesar 4.770,0089 $\mu \mathrm{W}, 10,1324 \mu \mathrm{W}$, dan $0,0017 \mu \mathrm{W}, 4)$ Nilai rata-rata energi listrik untuk anoda Tembaga $(\mathrm{Cu})$, Aluminium $(\mathrm{Al})$, dan Besi $(\mathrm{Fe})$ secara berurutan adalah sebesar 47.700,0889 $\mu \mathrm{J}, 101,3232 \mu \mathrm{J}$, dan 0,0169 $\mu \mathrm{J}, 5$ ) Kualitas rancangan modul yang digunakan sebagai bahan pembelajaran listrik dinamis adalah; rata-rata validasi isi sebesar $84,50 \%$ dalam katagori valid dan rata-rata validasi grafika sebesar 85,60 dalam katagori sangat valid. Hal ini menyatakan bahwa rancangan modul dapat digunakan sebagai bahan pembelajaran, 6) Terdapat peningkatan kemampuan kognitif siswa pada pokok bahasan listrik dinamis dibuktikan dengan nilai $\mathrm{N}$-gain untuk kelompok tinggi sebesar 0,75 (tinggi), kelompok sedang sebesar 0,46 (sedang), dan kelompok rendah sebesar 0,30 (sedang), dan 7) Terdapat perbedaan hasil belajar kognitif siswa pada kelompok tinggi, sedang dan rendah dibuktikan $\mathrm{F}_{\text {hitung }}$ sebesar 23,05 dan $\mathrm{F}_{\text {tabel }}$ sebesar 3,34 pada taraf signifikansi $5 \%$. $\mathrm{F}_{\text {hitung }}>\mathrm{F}_{\text {tabel }}$, sehingga $\mathrm{H}_{\mathrm{a}}$ diterima dan $\mathrm{H}_{0}$ ditolak.
\end{abstract}

Kata kunci: kulit durian, energi listrik, modul pembelajaran, SMPN 11 Kota Bengkulu

\section{PENDAHULUAN}

Energi listrik merupakan kebutuhan kehidupan sehari-hari masyarakat dunia. Pertumbuhan pembangkit listrik meningkat seiring dengan bertambahnya permintaan energi dinamis dalam industrialisasi serta modernisasi (Shariar dan Bustam, 2012). Upaya pembangkit listrik banyak dilakukan dengan menggunakan bahan bakar fosil seperti batu bara, minyak bumi, 
dan gas alam yang tidak dapat diperbaharui (BPPT, 2014). Potensi sumber energi terbarukan (renewable energy) yang tersedia sangat melimpah namun hingga kini belum terkelola secara optimal (Choo et al., 2014). Tudorache dan Kreindler (2010) menyatakan bahwa potensi pasar di masa depan dari pembangkit listrik melalui tanaman lebih menguntungkan karena dapat bermanfaat untuk mengintegrasikan sistem penyimpanan termal sederhana dan tepat guna.

Indonesia merupakan negara agraris kaya akan tanaman yang sangat berpotensi untuk dimanfaatkan sebagai energi terbarukan yaitu energi listrik. Sumber energi terbarukan lainnya seperti surya, angin, biomassa, tersedia hanya untuk waktu tertentu (Tilahun et al., 2014). Di Indonesia berusaha mencari sumber energi alternatif, akibat persediaan minyak bumi di dunia yang mulai berkurang, sehingga perlu dicari sumber energi alternatif (Nugraheni, 2015).

Pemanfaatan tanaman sebagai sumber energi listrik dapat memperbaiki taraf hidup, baik produsen, pengguna, bahkan lingkungan. Banyak Negara luar saat ini mengelola sumber energi listrik tanaman dengan menerapkan teknologi yang dapat diterima oleh masyarakat dan berbasis ramah lingkungan (Strik et al., 2008). Pembangkit listrik tanaman memiliki keuntungan seperti biaya produksi rendah, dapat melestarikan lingkungan, dan dapat mengurangi emisi gas rumah kaca. Hal ini juga akan memberikan kontribusi langsung kepada strategi pengurangan gas $\mathrm{CO}_{2}$ (Heijne et al., 2010).

Energi listrik tanaman dapat diperoleh dari adanya proses perubahan energi surya menjadi senyawa-senyawa kompleks tanaman (Jerkovic et al., 2011). Energi listrik tenaga tanaman juga tersedia dari adanya aktivitas mikroba tanah yang menguraikan karbon menjadi cadangan makanan dan secara langsung mempengaruhi $\mathrm{pH}$ (keasaman) yang menghasilkan ion-ion, dengan demikian ketidakseimbangan kimia tersebut terjadi karena adanya metabolisme tanaman (Tilman et al., 2006).

Banyak tanaman menghasilkan arus listrik, sebagian besar tanaman yang digunakan peneliti menghasilkan energi listrik langsung melalui proses yang lebih efektif dan populer (Shariar dan Bustam, 2012). Salah satu pemanfaatan tanaman sebagai energi terbarukan juga dapat menggunakan limbah kulit durian yang selama ini tidak dimanfaatkan dengan baik karena karakternya yang sukar terurai sehingga berpotensi menjadi salah satu limbah hayati yang menyebabkan pencemaran lingkungan (Rosmawati, 2016).

Pemanfaatan kulit durian sebagai sumber energi terbarukan merupakan salah satu upaya yang tepat dalam mengurangi masalah yang ditimbulkan, hal ini dapat diintegrasikan dengan proses pendidikan yang ada. Berdasarkan pengalaman mengajar selama dua puluh tahun di SMPN 11 Kota Bengkulu. Masalah pokok dalam pembelajaran pada pendidikan formal (sekolah) sejauh ini masih rendahnya daya serap peserta didik. Hal ini nampak merata pada hasil belajar yang masih sangat rendah. Ini merupakan hasil pembelajaran yang masih bersifat konvensional dan tidak menyentuh ranah dimensi peserta didik itu sendiri, yaitu bagaimana sebenarnya pengertian belajar itu. Dalam arti yang lebih umum, bahwa guru masih menjadi pusat proses pembelajaran hingga saat ini, sehingga siswa menjadi pasif. Permasalahan tersebut dapat diupayakan dengan menerapkan pembelajaran di sekolah model cara berpikir tinggi atau higher order thinking skills (HOTS). Dengan pengembangan model tersebut dapat menghasilkan siswa berkemampuan berpikir kritis, keterampilan berkomunikasi baik, berkolaborasi, berpikir kreatif, dan percaya diri dalam mempersiapkan diri di era milenium.

Siswa mempelajari IPA pada ranah kognitif yang terendah dan tidak dibiasakan untuk mengembangkan afektif dan psikomotornya. Fakta di kelas menunjukkan bahwa banyak siswa yang cenderung tidak mau berfikir secara mandiri. Cara berfikir yang dikembangkan dalam kegiatan belajar belum menyentuh ranah afektif dan psikomotor (Hudha et al., 2012). Pembelajaran di SMPN 11 Kota Bengkulu yang telah menerapkan Kurikulum 2013 yang mengacu pada pembelajaran abad 21 yang diharapkan dapat mempersiapkan siswa supaya memiliki kemampuan hidup sebagai pribadi dan warga negara yang beriman, produktif, kreatif, inovatif dan afektif. Serta mampu berkontribusi 
pada kehidupan bermasyarakat, berbangsa, bernegara, dan peradaban dunia.

Metode Discovery learning merupakan metode mengajar yang menggunakan teknik penemuan dan merupakan proses mental (misalnya: mengamati, menggolongkan, membuat dugaan, menjelaskan, mengukur, membuat kesimpulan dan sebagainya) dimana siswa menyesuaikan suatu konsep atau prinsip. Dalam teknik ini siswa dibiarkan menemukan sendiri atau mengalami proses mental itu sendiri, guru hanya membimbing dan memberi intruksi (Roestiyah, 2001).

Berdasarkan latar belakang di atas maka peneliti tertarik untuk melakukan penelitian yang berjudul "Merancang Modul Pembelajaran IPA Menggunakan Kulit Durian Untuk Meningkatkan Kemampuan Kognitif Siswa Kelas IX SMPN 11 Kota Bengkulu".

\section{METODE PENELITIAN}

Penelitian ini adalah merancang modul pembelajaran menggunakan limbah kulit durian sebagai sumber energi listrik pada pembelajaran listrik dinamis untuk meningkatkan kemampuan kognitif siswa kelas IX.C SMPN 11 Kota Bengkulu. Metode yang digunakan Discovery learning dengan menerapkan pembelajaran HOTS.

Variabel bebas adalah variabel yang menjadi sebab timbulnya atau berubahnya variabel dependen (variabel terikat). Variabel bebas dalam penelitian ini adalah jumlah limbah ekstrak kulit durian.

Variabel terikat yang dipengaruhi atau yang menjadi akibat, karena adanya variabel bebas. Variabel terikat dalam penelitian ini adalah beda potensial, kuat arus, listrik dinamis, dan prestasi belajar yang diperoleh dari hasil tes akhir (posttest).

Populasi dalam penelitian ini adalah seluruh siswa kelas IX SMP Negeri 11 Kota Bengkulu Tahun Ajaran 2018/2019. Teknik sampel yang digunakan dalam penelitian ini adalah teknik cluster sampling. Teknik ini digunakan karena populasi tidak terdiri dari individu-individu, tetapi merupakan kelompok-kelompok individu (cluster). Sampel yang digunakan dalam penelitian ini adalah kelas IX.C SMP Negeri 11
Kota Bengkulu Tahun Ajaran 2018/2019 yang berjumlah 31 orang siswa.

Variabel bebas dalam penelitian ini adalah model pembelajaran Problem Based Learning, sedangkan variabel terikatnya adalah hasil belajar fisika siswa. Instrumen penelitian terdiri atas perangkat pembelajaran (modul) dan instrumen pengumpulan data (soal pretest dan posttest sebanyak 30 soal). Sebelum digunakan, semua instrumen tersebut dilakukan uji validitas. Untuk modul dilakukan uji validitas isi dan grafika oleh dua orang dosen dan satu orang guru fisika. Sedangkan instrument tes kognitif dilakukan uji validitas isi dan reliabilitas (ICC) oleh dua orang dosen dan satu orang guru fisika (sebagai judgment experts). Setelah itu, soal tes kognitif diujikan di lapangan. Hasil yang diperoleh digunakan untuk menguji validitas, reliabilitas, tingkat kesukaran dan daya beda soal. Berdasarkan hasil uji tersebut diperoleh: (1) tes kognitif yang diterima 10 butir dengan realibilitas sangat tinggi $\left(r_{11}=0,96\right)$, (2) sebanyak 5 butir soal tidak valid dan dibuang. Data penelitian ini berupa hasil belajar kognitif siswa. Data tersebut dianalisis dengan statistik deskriptif dan inferensial. Analisis deskriptif digunakan untuk mendeskripsikan hasil belajar kognitif siswa kelompok tinggi, sedang dan rendah. Sedangkan analsisis inferensial digunakan untk menguji hipotesis yang telah dirumuskan pada taraf signifikansi 5\%.

\section{HASIL DAN PEMBAHASAN}

1. Nilai Kuat arus listrik, Tegangan Listrik, Daya Listrik dan Energi Listrik

Dari data hasil penelitian nilai kuat arus listrik, tegangan dan daya listrik dari kulit durian didapat variasi nilai kuat arus listrik, tegangan dan daya listrik berdasarkan jenis anoda yang digunakan. Anoda yang digunakan dalam penelitian ini adalah Tembaga $(\mathrm{Cu})$, Aluminium $(\mathrm{Al})$, dan Besi $(\mathrm{Fe})$. Tembaga $(\mathrm{Cu})$ menghasilkan nilai kuat arus listrik, tegangan, dan daya listrik yang paling besar disusul oleh Aluminium (Al) dan Besi $(\mathrm{Fe})$. Secara berurutan rata-rata nilai kuat arus listrik, tegangan, dan daya listrik menggunakan anoda Tembaga $(\mathrm{Cu})$ adalah 2,9717 Volt, 1.175,2778 $\mu \mathrm{A}, 4.770,0089 \mu \mathrm{W}$. Secara berurutan rata-rata nilai kuat arus listrik, tegangan, dan daya listrik menggunakan anoda 
Aluminium (Al) adalah 1,2772 Volt, 5,8911 $\mu \mathrm{A}$, $10,1324 \mu \mathrm{W}$. Secara berurutan rata-rata nilai kuat arus listrik, tegangan, dan daya listrik menggunakan anoda Besi (Fe) adalah 0,4556 Volt, $0,0030 \mu \mathrm{A}, 0,0017 \mu \mathrm{W}$.

Dari nilai kuat arus listrik dan tegangan yang diperoleh dari penelitian selanjutnya dihitung besarnya energi listrik yang dihasilkan untuk masing anoda selama 10 sekon. Besarnya nilai energi listrik untuk anoda Tembaga $(\mathrm{Cu})$, Aluminium ( $\mathrm{Al})$, dan Besi $(\mathrm{Fe})$ secara berurutan adalah sebesar 47.700,0889 $\mu \mathrm{J}, 101,3232 \mu \mathrm{J}$, dan $0,0169 \mu \mathrm{J}$.

Besarnya nilai kuat arus listrik, tegangan, dan daya listrik memiliki perbedaan untuk masing-masing anoda yang digunakan. Nilai terbesar diperoleh pada anoda Tembaga $(\mathrm{Cu})$, disusul anoda Aluminium (Al), dan yang paling rendah pada anoda Besi $(\mathrm{Fe})$. Perbedaan nilai ini dikarenakan masing-masing anoda memiliki sifat dan karakter yang berbeda sebagai konduktor listrik. Dalam proses pengambilan data kuat arus listrik dan tegangan dari kulit durian yang dilakukan peneliti, beberapa kali diperoleh nilai yang berbeda mencolok untuk 1 jenis pengambilan data. Pengambilan data harus dilakukan berulang kali sehingga menghasilkan angka yang lebih stabil. Hal ini bisa terjadi karena peneliti kurang teliti dalam mengkalibrasi alat, alat kurang sensitif dalam membaca angka yang kecil, kekuatan baterai alat yang digunakan, dan pengaruh keasaman larutan yang dilakukan.

\section{Rata-rata pestest dan Postest}

Hasil pretest dan postest ada pada gambar 1 .

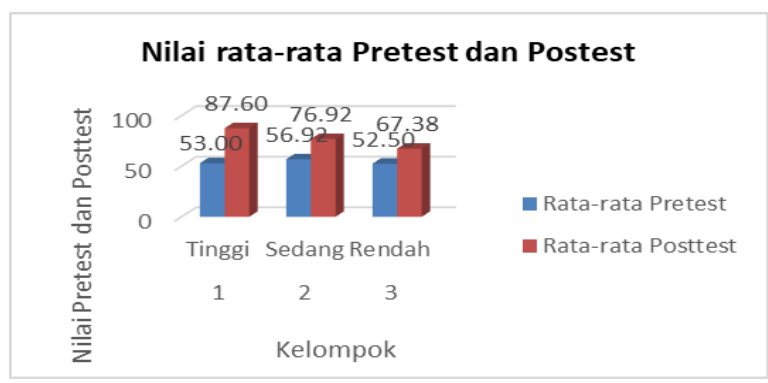

Gambar 1. Grafik nilai rata-rata pretest dan postest
Dari gambar terlihat bahwa masing-masing kelompok mengalami peningkatan rata-rata nilai postest sebesar 34.60; kelompok sedang sebesar 20,00; kelompok rendah sebesar 14,88.

\section{Simpangan Baku}

Kelompok tinggi memiliki simpangan baku sebesar 59.6 tinggi dan kelompok sedang memiliki 25.74. Hal ini mengindikasikan bahwa kelompok tinggi memiliki sebaran nilai yang lebih tinggi dari kelompok lainya.

\section{Perhitungan Gain}

Kelompok tinggi memiliki nilai -gain lebih tinggi dari kelompok lainya sebesar 0.75 dalam kategori tinggi. kelompok sedang memiliki nilai $\mathrm{N}$-gain sebesar 0.46 dalam kategori sedang. kelompok rendah memiliki nilai $\mathrm{N}$-gain paling rendah sebesar 0.30 dalam kategori sedang. Hal ini berarti bahwa kelompok tinggi memiliki peningkatan nilai yang lebih tinggi dari kelompok lainya.

\section{Analisis Inferensial}

a. Uji Homogenitas

Uji Homogenitas digunakan untuk menentukan apakah varian ketiga kelompok data dalam penelitian ini homogen, jika data homogen, maka analisis varian selanjutnya dapat dilakukan. Dari perhitungan yang dilakukan diperoleh $F_{\text {hitung }}$ sebesar 2.32 dengan dk pembilang 9 dan dk penyebut 7 , maka harga $\mathrm{F}$ tabel untuk taraf signifikasi $5 \%=3.68$ dan $1 \%=6.72$. Ternyata $\mathrm{F}_{\text {hitung }}$ $<\mathrm{F}_{\text {tabel }}(2.32<3.68<6.72)$ Dengan demikian dapat disimpulkan bahwa varian data yang dianalisis homogen, sehingga perhitungan anava dapat dilakukan.

b. Pengujian Hipotesis

Setelah diketahui bahwa data dalam penelitian ini homogen maka analisis varian selanjutnya dapat dilakukan menggunakan Uji Anava Satu Jalur. Ringkasan perhitungan anava dapat dilihat pada tabel 1. 
Tabel 1. Ringkasan Perhitungan Anava

\begin{tabular}{|c|c|c|c|c|c|c|}
\hline $\begin{array}{l}\text { Sumber } \\
\text { Varians }\end{array}$ & $\begin{array}{c}\text { Jumlah } \\
\text { Kuadrat } \\
\text { (JK) }\end{array}$ & $\begin{array}{c}\text { Derajat } \\
\text { bebas }\end{array}$ & $\begin{array}{c}\text { Kuadrat } \\
\text { Rerata } \\
\text { (KR) }\end{array}$ & $\mathbf{F}_{\text {hitung }}$ & $\begin{array}{c}\text { Taraf } \\
\text { Signifikansi }\end{array}$ & Keputusan \\
\hline $\begin{array}{c}\text { Antar } \\
\text { kelompok }\end{array}$ & $1.839,51$ & 2 & 919,76 & \multirow{3}{*}{23,05} & \multirow{3}{*}{$\begin{array}{c}\alpha=0,05 \\
\mathrm{~F}_{\text {tabel }}=3,34\end{array}$} & \multirow{3}{*}{$\begin{array}{c}\mathrm{F}_{\text {hitung }}>\mathrm{F}_{\text {tabel }} \\
23,05>3,35 \\
\text { Jadi } \mathrm{H}_{\mathrm{a}} \text { diterima } \\
\text { untuk taraf } \\
\text { signifikansi 5\% }\end{array}$} \\
\hline $\begin{array}{c}\text { Dalam } \\
\text { kelompok }\end{array}$ & $1.117,20$ & 28 & 39,90 & & & \\
\hline Total & - & 30 & - & & & \\
\hline
\end{tabular}

Dari tabel dapat dilihat bahwa $F_{\text {hitung }}$ sebesar 23.05 Dengan dk pembilang 2 dan dk Penyebut 28 , maka harga $\mathrm{F}_{\text {tabel }}$ untuk taraf signifikasi $5 \%=$ 3.34. Ternyata $F_{\text {hitung }}>F_{\text {tabel }}$ sehingga Ho ditolak dan Ha diterima. Kesimpulan dari perhitungan anava adalah terdapat perbedaan hasil belajar kognitif peserta didik pada kelompok tinggi sedang dan rendah dengan menggunakan modul. Dengan demikian terdapat peningkatan kemampuan kognitif dengan belajar menggunakan kulit durian pada pokok bahasan Listrik dinamis dan pembelajaran menggunakan modul.

\section{KESIMPULAN}

Berdasarkan hasil penelitian dan pembahasan dapat ditarik kesimpulan sebagai berikut: 1) Nilai rata-rata kuat arus listrik yang dihasilkan dari ekstrak kulit durian menggunakan anoda Tembaga $(\mathrm{Cu})$, Aluminium (Al), dan Besi (Fe) secara berurutan sebesar 1.175,2778 $\mu \mathrm{A}$, $5,8911 \mu \mathrm{A}$, dan $0,0030 \mu \mathrm{A}, 2)$ Nilai rata-rata tegangan listrik yang dihasilkan dari ekstrak kulit durian menggunakan anoda Tembaga $(\mathrm{Cu})$, Aluminium ( $\mathrm{Al}$ ), dan Besi $(\mathrm{Fe})$ secara berurutan sebesar 2,2917 Volt, 1,2772 Volt, dan 0,4556 Volt, 3) Nilai rata-rata daya listrik yang dihasilkan dari ekstrak kulit durian menggunakan anoda Tembaga $(\mathrm{Cu})$, Aluminium (Al), dan Besi (Fe) secara berurutan sebesar 4.770,0089 $\mu \mathrm{W}$, $10,1324 \mu \mathrm{W}$, dan $0,0017 \mu \mathrm{W}$, 4) Nilai rata-rata energi listrik untuk anoda Tembaga $(\mathrm{Cu})$, Aluminium ( $\mathrm{Al})$, dan Besi $(\mathrm{Fe})$ secara berurutan adalah sebesar 47.700,0889 $\mu \mathrm{J}, 101,3232 \mu \mathrm{J}$, dan $0,0169 \mu \mathrm{J}, 5)$ Kualitas rancangan modul yang digunakan sebagai bahan pembelajaran listrik dinamis adalah; rata-rata validasi isi sebesar $84,50 \%$ dalam katagori valid dan rata-rata validasi grafika sebesar 85,60 dalam katagori sangat valid. Hal ini menyatakan bahwa rancangan modul dapat digunakan sebagai bahan pembelajaran, 6) Terdapat peningkatan kemampuan kognitif siswa pada pokok bahasan listrik dinamis dibuktikan dengan nilai $\mathrm{N}$-gain untuk kelompok tinggi sebesar 0,75 (tinggi), kelompok sedang sebesar 0,46 (sedang), dan kelompok rendah sebesar 0,30 (sedang), dan 7) Terdapat perbedaan hasil belajar kognitif siswa pada kelompok tinggi, sedang dan rendah dibuktikan $\mathrm{F}_{\text {hitung }}$ sebesar 23,05 dan $\mathrm{F}_{\text {tabel }}$ sebesar 3,34 pada taraf signifikansi $5 \%$. $\mathrm{F}_{\text {hitung }}>\mathrm{F}_{\text {tabel }}$, sehingga $\mathrm{H}_{\mathrm{a}}$ diterima dan $\mathrm{H}_{0}$ ditolak.

\section{DAFTAR PUSTAKA}

Badan Pengkajian dan Penerapan Teknologi. 2014. Outlook Energi Indonesia 2014: Pengembangan Energy Untuk Mendukung Program Substitusi BBM. Jakarta: Pusat Teknologi Pengembangan Sumberdaya Energi (PTPSE) BPPT.

Choo, Y. Y., J. Dayou, dan N. Surugau. 2014. Origin of Weak Electrical Energy Production from Living-lants. International Journal of Renewable Energy Research, 4(1): 198-203.

Heijne, T. A., D. P. Strik., H. V. Hamelers, and C. J. Buisman. 2010. Cathode Potential and Mass Transfer Determine Performance of Oxygen Reducing Biocathodes in Microbial Fuel Cells. Environmental science \& technology, 44(18): 7151-7156.

Hudha, A. M., Kes, M., S. P. Husamah, dan S. Hadi. 2012. Pendampingan Pengembangan Perangkat Pembelajaran Laboratorium untuk Menunjang Pelaksanaan Bagi Guru 
IPA Biologi SMP Muhammadiyah 1 Malang. Jurnal Dedikasi, 8: 43-51.

Jerkovic, V., Z. Spoljaric, and D. Sljivac. 2011. Stability Testing of a Small Biogas Plant in An Electric Power System. International journal of electrical and computer engineering systems, 2(2): 49-54.

Nugraheni, S. 2015. Pengembangan Energi Indonesia 2015-2019 dan Peluang Memanfaatkan Forum G20. Penelitian LPPM Universitas Katolik Parahyangan. Roestiyah, S. 2001. Pembelajaran dengan Menerapkan Metode Eksperimen di Sekolah. Bandung: PT. Remaja Rosdakarya.

Rosmawati, T. 2016. Pemanfaatan Limbah Kulit Durian Sebagai Bahan Baku Briket dan Pestisida Nabati. Biology Science and Education, 5(2): 159-170.

Shariar, K. F., dan A. H. Bustam. 2012. Waste to Energy: A New Dimension in Generating Electricity in Bangladesh. International
Journal of Engineering and

Technology, 4(4): 480-483.

Strik, D. P., Hamelers, H. V. M., Snel, J. F., and Buisman, C. J. 2008. Greenelectricity Production with Living Plants and Bacteria in A Fuel Cell. International Journal of Energy Research, 32(9): 870-876.

Tilahun, T., G. Coene, M. Temmerman, and O. Degomme. 2014. Spousal Discordance on Fertility Preference and Its Effect on Contraceptive Practice Among Married Couples in Jimma Zone, Ethiopia. Reproductive health, 11(1): 1-10.

Tilman, D., J. Hill, and C. Lehman. 2006. Carbon-Negative Biofuels from LowInputhigh-Diversity Grassland Biomass. Science, 314 (5805): 1598-1600.

Tudorache, T., and Kreindler, L. 2010.Design of A Solar Tracker System for PV Power Plants. Acta Polytechnica Hungarica, 7(1): 23-39. 